\title{
Darfur Crisis: Platforms, Partners and Peace Agreements The Pending Question: What Are the Reasons Behind the Failure?
}

\author{
Dr. Anwar Yousif Atta Al-Mannan \\ (Associate Professor), Center for Sudanese Studies, International College \\ Yangzhou University, P.R.C. \\ Faculty of Management Sciences and Economics, Rufaa, Al-Butana University, Sudan.
}

\begin{abstract}
This paper focused on the Darfur issue and discussed the reasons behind the repeated failure to achieve sustainable peace despite the many agreements, declarations of principles and platforms. The paper touched on the historical background of the agreements signed between the government and the armed movements, and the movements that splintered from the main movements, where the result has always been the collapse of the agreements.The historical approach is followed in this paper, as the most appropriate for this type of research work. The paper also adopted the questionnaire as a means of obtaining the initial information directly from the research community.The results of the analysis and their indicators were discussed, coupled with the historical background of the conflicts in Darfur and the reasons for the failure of previous agreements. The researcher has come up with a set of initial perceptions, through which a public debate on the Darfur crisis and the prospects for a sustainable solution can be initiated in a way that avoids repetition of past experiences, which have adopted traditional solutions, despite its inability to put an end to chronic historical tribal conflicts in Darfur.
\end{abstract}

DOI: $10.7176 / \mathrm{JEP} / 10-30-03$

Publication date:October $31^{\text {st }} 2019$

\section{Definition of main concepts}

The Janjaweed:

The Janjaweed are a militia that operate in western Sudan and eastern Chad. Using the United Nations definition,( the Janjaweed comprised Sudanese Arab tribes, the core of whom are from the Abbala background with significant recruitment from the Baggara people) ${ }^{(1)}$

\section{Hakoura:}

Hakoura is an area of land, given to a tribe, which borders its neighbors from other tribes. Within Hakoura, there is land given to minority tribes, under the supervision of the main tribe in Hakoura. The leader of the tribe is the organizer of the farms, pastures and water bodies, and has the power to grant and prevent. There are powers, for minority tribal leaders, to avoid friction between farmers and herders. "(2)

Hakoura is an Arabic word, compiled by Hawakir, and the word Hakoura in the Fur language is Ro - and collected - ROTA. ${ }^{(3)}$

\section{Sustainable Peace:}

Sustainable peace in this paper, means that, peace provides the right to dignified, safe, stable and easy human needs for present generations, without harming the right of future generations to enjoy the same benefits at the same level or better.

\section{Introduction:}

Darfur has a specificity based on historical and geographical data as well as the social and cultural environment. Darfur has been an independent state for more than 500 years in the name of the Sultanate of Darfur, and its rulers were from the Fur tribe, so the Sultanate took the name of Darfur, the largest tribes in the region. Sultan Ali Dinar, the last ruler of the Sultanate of Darfur, tried to resist British colonialism and fought several battles against the British army. Darfur is home to more than 60 tribal group who speak more than 80 local languages and dialects and are a diverse mix of Arab and African tribes. They are extremely intolerant of race and tribe and are the most ethnically cohesive in Sudan. This has been reflected in the many tribal conflicts and their ongoing resolution projects, which have been transformed into tools and systems supported by deep-rooted customs and traditions, derived from positive cultural and social cohesion, leading to the prevalence of Islamic and local values, customs and traditions, which have always been a true reference for behavior, conflict resolution and discipline at the individual and community level. . These traditions and customs are guarded by powerful tribal

1 http://www.allafrica.com/integrated regional information/2004

2Noam Choucair: Geography and History of Sudan, Part I, Beirut, 1967, p. 472.

3 Dr. M. Al-Sharif: Land Ownership and Governance in Darfur, Paper presented to the Peace building Workshop, Center for Western Sudan Studies, Nyala, 2005, p. 6. 
institutions, represented by tribal elders, mayors, sultans, charities, Hakama, etc....

This diversity and social specificity, dominated by tribal character and its institutions, resulted in subsequent development ramifications in the course of tribal conflicts and wars. With a regional, political, socioeconomic cover, and despite its local and regional orientation, it has taken on a new, national and even global character, in an accelerated and spectacular manner.

Darfur has become the headline in the widely read and written media, but also one of the most famous cases of conflicts in contemporary human history. It has also surpassed the South Sudan War in terms of victims, refugees, displaced persons and material and moral losses. The war in Darfur now lasted fifteen years, during which more than fifteen agreements were signed, as well as platforms, axes and agenda.

The unanswered question arises: What are the reasons behind the failure of these agreements to achieve peace?

\section{Darfur Population:}

The population of Darfur is approximately 7.5 million, according to the last census in 2008 . They use local languages as well as Arabic. Darfur is home to a large number of tribes, which are divided into two groups, "settled tribal groups" in rural areas such as: "Fur", "Masalit", "Bargou", "Alberti" Zaghawa "," Mararit "," Dajo "," Altnjr "' Hausa, Tama, and Al Barqad in addition to the nomadic tribal groups that move from one place to another such as: "Abala", "Mahamid", "Mehriya", "Bani Hussein", "Rizeigat", "Ma'ale" and Salamat and Bani Halba Most of the settled tribes are African, and speak local languages in addition to Arabic, some of them Arabs, while the majority of nomadic tribes are Arabs.

\section{Darfur Economy:}

There are abundant forests of gum in the Darfur region, as well as cotton and tobacco plantations in the southwest of the region. Various fruit trees are also growing in the Jebel Marra area, which is characterized by a Mediterranean climate, as well as vegetables in the valleys and coves.

In some areas of Darfur, wheat, maize, millet and others are grown.

Darfur is characterized by a large animal wealth of camels, sheep and cattle, which was affected when the drought hit the region in the early eighties. In addition to animals and agriculture, the region has minerals and petroleum. ${ }^{(1)}$ 


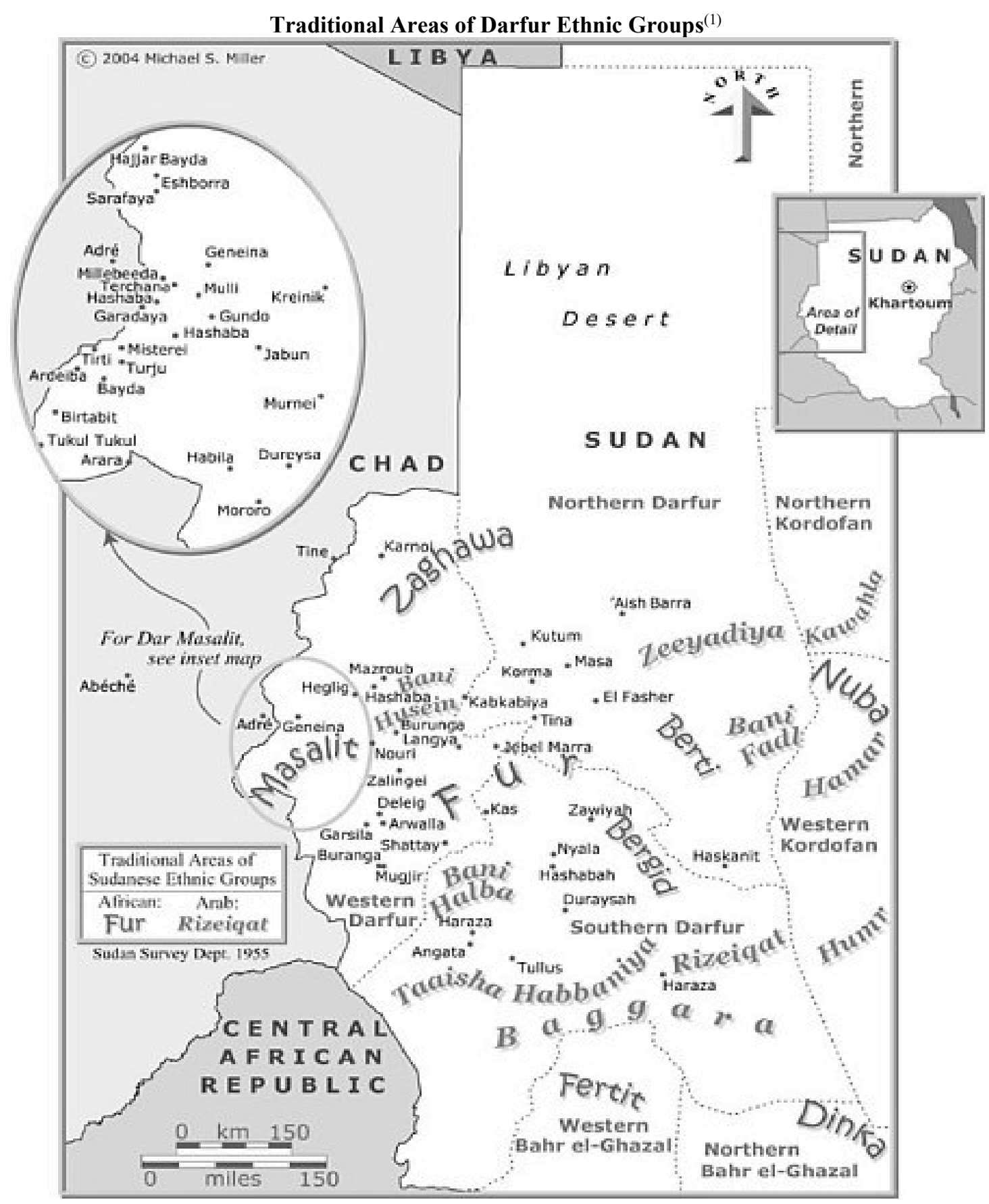

\section{Political and Armed Movements in Darfur:}

Before and after Sudan's independence in 1956, political activities in Darfur were carried out by northerners and local tribal leaders.

The harbingers of regional political movements emerged in 1957 with the Red Flames Movement, a clandestine movement, aimed at raising the political awareness of the people of Darfur. During the government of General Ibrahim Abboud (1957-1964).

Later, in 63/1964, the Sony movement was led by soldiers from Darfur, who took part in the war in southern Sudan, and returned to Darfur with political awareness. This movement was violently suppressed.

After the success of the October 1964 revolution, the Rural Union was formed from the following unions: the Southern Front, the General Union of the Nuba Mountains, the Union of North and South Anqisna, the Beja Union, the Renaissance Kordofan Front and the Renaissance Front of Darfur, with the aim of demanding economic development and political independence in the formulation of plans and programs

1 www.geographyabout.com/library/maps/b/sudan07. 
The Organization of Western Sudan was formed in 77/1979 during the reign of President Nimeiri, under the leadership of Captain Jacob Ismail.

In 1988, the Arab tribes group emerged on the scene, which was the nucleus of the current Janjaweed militia, then in 1991, the so-called Bolad Movement, led by the rebel Islamist Daoud Bolad, who joined the SPLM, arrived at Jebel Marra, and finally, his movement was violently suppressed by the government. ${ }^{(1)}$

The current armed conflict in Darfur started in February 2003, when two rebel groups, the Sudan Liberation Movement and the Justice and Equality Movement (JEM), began to declare war on the Sudanese government, which is accused of persecuting non-Arab Darfuris. The government responded with massive and very violent attacks, which were categorized by several sides as a campaign of ethnic cleansing against non-Arab Darfuris.

These attacks killed hundreds of thousands of civilians, burned villages and destroyed property, and Sudanese President Omar al-Bashir was accused of genocide, war crimes, and crimes against humanity by the International Criminal Court (ICC). ${ }^{(2)}$

The parties directly involved in the current conflict in Darfur are the SAF, the police and the Janjaweed. The Janjaweed are known as Sudanese government-backed militias, made up of Arab pastoral tribes, camel herders. Most of the other Arab groups in Darfur remained uninvolved. The other side includes rebel groups, especially the Sudan Liberation Movement and the Justice and Equality Movement, which are made up of nonArab Muslim ethnic groups such as the Fur, Zaghawa and Masalit.

Although the Sudanese government denies supporting the Janjaweed, there are allegations that it supports the militia with financial assistance, weapons, and joint attacks, particularly against civilians. ${ }^{(3)}$ The death toll is estimated to be several hundred thousand, either due to fighting or hunger and disease. Massive displacement has forced millions of people to go to IDP camps, refugee camps or cross borders, in what has been described as the worst humanitarian crisis of our time ${ }^{(4)}$.

Former US Secretary of State Colin Powell called the situation genocide ${ }^{(5)}$.

There are several different interpretations of the roots of the current conflict. The first interpretation supports the notion of land conflict between semi-nomad sheep herders and non-nomadic farmers; the conflict over water is also a major cause of conflict.

On 25 March 2003, the rebels occupied the SAF Tin village camp, near the Chadian border, and seized large quantities of ammunition and weapons. ${ }^{(6)}$

On April 25, 2003, a joint SLA and JEM force entered El Fasher and attacked an air base at the airport, destroying four Antonov bombers and helicopters on the ground, killing 75 soldiers, pilots, technicians, and 32 prisoners, including an air base commander, a brigade. Sudan.

It was a qualitative and successful military operation that did not occur during the 20 years of war in South

After the successful of El Fasher military operation, the SAF losses continued, and the government then relied on three elements to divert the war to the SAF:

1. Military Intelligence.

2. Air forces.

3. The Janjaweed: become the focus of the government's new counterinsurgency strategy.

1 Sharif Dahab, History of Conflicts in Darfur, Free Pens, JEM Website, April 2018

2Issue of arrest warrant for Sudanese President, BBC Arabic, Published March 4, 2009, filed August 8, 2017.

3Mahmoud Yusuf, Background to the genocide in Darfur, Darfurna.homestead.com

4 Gerard Brunner, the Mysterious Darfur Massacres, Hatters \& Co. Printing, London, 2005

5http://www.un.org/news/dh/Sudan/com_Inq_darfur.pdf\#search

6 http://newsbbc.co.uk/hi/arabic/news/newsid 7922000/7922947/stm 


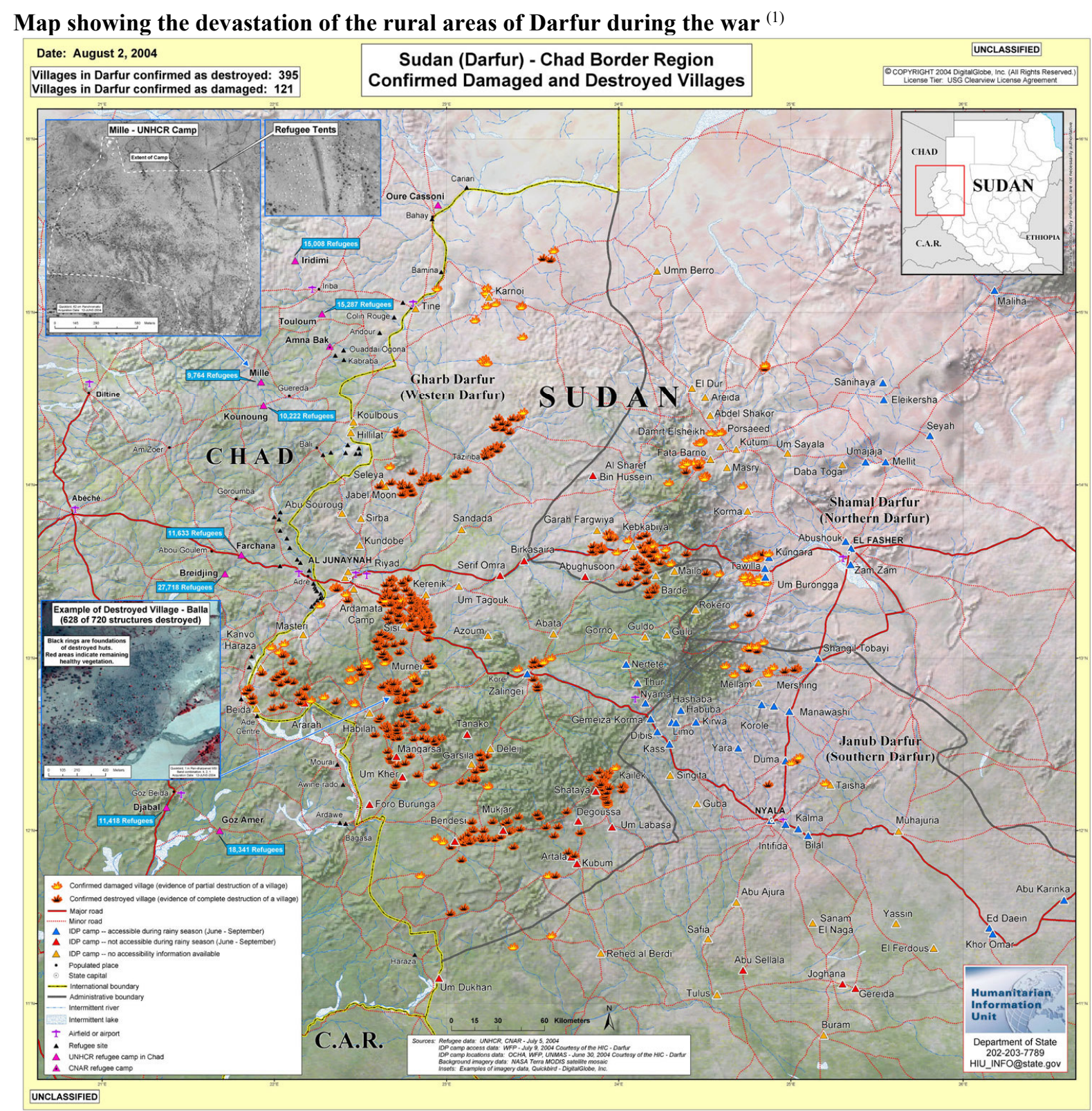

The main agreements signed between the Government of Sudan and the armed political opposition movements in Darfur:

The table below summarizes the main agreements signed between the Government of Sudan and the armed political opposition movements in Darfur from 2004 to 2011 in various African and Arab capitals. Witnesses to these agreements were peace partners from different countries of the world, especially the African neighbors and international and continental regional organizations, at various stages of the Darfur crisis.

The tables show the most important items of these agreements, their outputs and the reasons for their failure.

\footnotetext{
${ }^{1}$ Humanitarian Information Unit, Department of State, 202-203-7789, HIU_INFO@state.gov
} 


\begin{tabular}{|c|c|c|c|c|c|}
\hline Date & $\begin{array}{l}\text { The name of } \\
\text { the agreement }\end{array}$ & Place of signature & Objectives & Results & $\begin{array}{lr}\text { Reasons } & \text { for } \\
\text { success } & \text { or } \\
\text { stumbling } & \\
\end{array}$ \\
\hline 2004 & $\begin{array}{l}\text { Protocol on } \\
\text { humanitarian } \\
\text { assistance }\end{array}$ & $\begin{array}{l}\text { Chadian } \\
\text { capital (N'Djamena) }\end{array}$ & $\begin{array}{l}\text { 1. Cease-fire } \\
\text { 2. Pass } \\
\text { humanitarian aid to } \\
\text { displaced persons } \\
\text { and refugees } \\
3 \text { - Open safe } \\
\text { corridors }\end{array}$ & $\begin{array}{l}\text { The } \\
\text { agreement did } \\
\text { not hold for a } \\
\text { long time }\end{array}$ & $\begin{array}{l}\text { The agreement } \\
\text { was breached } \\
\text { by the } \\
\text { conflicting } \\
\text { parties }\end{array}$ \\
\hline 2004 & $\begin{array}{l}\text { Agreement } \\
\text { for the } \\
\text { Establishment } \\
\text { of the } \\
\text { Ceasefire } \\
\text { Commission } \\
\text { between the } \\
\text { Sudan } \\
\text { Liberation } \\
\text { Movement } \\
\text { and the } \\
\text { Government } \\
\text { S }\end{array}$ & $\begin{array}{l}\text { Ethiopian } \\
\text { capital } \\
\text { Ababa) }\end{array}$ & $\begin{array}{l}\text { 1. Cease-fire } \\
2 \quad-\quad \text { Open safe } \\
\text { corridors } \\
\text { 3. Deployment of } \\
\text { observers }\end{array}$ & $\begin{array}{l}\text { The } \\
\text { agreement did } \\
\text { not hold up } \\
\text { very much }\end{array}$ & $\begin{array}{l}\text { The agreement } \\
\text { was breached } \\
\text { by the } \\
\text { conflicting } \\
\text { parties and } \\
\text { accusations of } \\
\text { non-compliance } \\
\text { were exchanged }\end{array}$ \\
\hline 2004 & $\begin{array}{l}\text { Protocol to } \\
\text { improve the } \\
\text { humanitarian } \\
\text { situation in } \\
\text { Darfur }\end{array}$ & $\begin{array}{l}\text { The Nigerian } \\
\text { capital ( Abuja ) }\end{array}$ & $\begin{array}{l}\text { 1. Allow the } \\
\text { distribution of } \\
\text { humanitarian relief } \\
\text { 2. Provision of } \\
\text { health services and } \\
\text { water services } \\
\text { 3. Environmental } \\
\text { sanitation } \\
\text { 4. Attention to and } \\
\text { protection of the } \\
\text { environment } \\
\text { 5. Strengthening the } \\
\text { security situation }\end{array}$ & $\begin{array}{l}\text { The situation } \\
\text { is much } \\
\text { improved in } \\
\text { the camps }\end{array}$ & $\begin{array}{l}\text { Great } \\
\text { cooperation by } \\
\text { the } \\
\text { international } \\
\text { community and } \\
\text { donors }\end{array}$ \\
\hline 2004 & $\begin{array}{l}\text { Protocol on } \\
\text { security } \\
\text { arrangements } \\
\text { in accordance } \\
\text { with the First } \\
\text { N'Djamena } \\
\text { Convention }\end{array}$ & $\begin{array}{l}\text { The Nigerian } \\
\text { capital( Abuja) }\end{array}$ & $\begin{array}{l}\text { Strengthening the } \\
\text { security situation }\end{array}$ & $\begin{array}{l}\text { Lack of } \\
\text { application on } \\
\text { the ground }\end{array}$ & $\begin{array}{l}\text { The weakness of } \\
\text { the parties' } \\
\text { confidence in } \\
\text { each other and } \\
\text { the beginning of } \\
\text { the activity of } \\
\text { the armed } \\
\text { movements }\end{array}$ \\
\hline 2005 & $\begin{array}{l}\text { Declaration of } \\
\text { Principles in } \\
\text { Abuja }\end{array}$ & Abuja & $\begin{array}{l}\text { To lay down the } \\
\text { basic principles that } \\
\text { can guide the } \\
\text { negotiators to solve } \\
\text { the Darfur problem }\end{array}$ & $\begin{array}{l}\text { The beginning } \\
\text { of direct } \\
\text { negotiations } \\
\text { between the } \\
\text { government } \\
\text { and the } \\
\text { armed } \\
\text { movements of } \\
\text { the Sudan } \\
\text { Liberation } \\
\text { Army and the } \\
\text { Justice and } \\
\text { Equality } \\
\text { Movement }\end{array}$ & $\begin{array}{l}\text { The } \\
\text { intervention of } \\
\text { the } \\
\text { international } \\
\text { community, the } \\
\text { prequalification } \\
\text { of the } \\
\text { negotiators and } \\
\text { the guarantee of } \\
\text { the } \\
\text { implementation } \\
\text { of } \\
\text { agreement any } \\
\text { reached. }\end{array}$ \\
\hline
\end{tabular}




\begin{tabular}{|c|c|c|c|c|c|}
\hline Date & $\begin{array}{l}\text { The name of } \\
\text { the agreement }\end{array}$ & Place of signature & Objectives & Results & $\begin{array}{lr}\text { Reasons } & \text { for } \\
\text { success } & \text { or } \\
\text { stumbling } & \\
\end{array}$ \\
\hline 2006 & $\begin{array}{l}\text { Darfur Peace } \\
\text { Agreement }\end{array}$ & Abuja & $\begin{array}{l}\text { Solve the problem of } \\
\text { Darfur and stop the } \\
\text { war }\end{array}$ & $\begin{array}{l}\text { The } \\
\text { agreement } \\
\text { was signed } \\
\text { with Minni } \\
\text { Arko Minawi, } \\
\text { head of the } \\
\text { Sudan } \\
\text { Liberation } \\
\text { Movement } \\
\text { (SLM). } \\
\text { Denying the } \\
\text { signing of the } \\
\text { agreement: } \\
\text { Dr. Khalil } \\
\text { Ibrahim, } \\
\text { President of } \\
\text { the Justice } \\
\text { and Equality } \\
\text { Movement } \\
\text { and Abdel } \\
\text { Wahid } \\
\text { Mohamed } \\
\text { Ahmed, head } \\
\text { of the Sudan } \\
\text { Liberation } \\
\text { Army } \\
\text { Movement. } \\
\text { And finally } \\
\text { the collapse of } \\
\text { the agreement } \\
\text { after the } \\
\text { return of } \\
\text { Minawi to } \\
\text { take up arms }\end{array}$ & $\begin{array}{l}1 \text { - rejection of } \\
\text { the movement } \\
\text { Abdul Wahid } \\
\text { and the } \\
\text { movement of } \\
\text { Dr. Khalil } \\
\text { signing the } \\
\text { agreement } \\
\text { 2. Cluster } \\
\text { fragmentation } \\
\text { in armed } \\
\text { movements. } \\
3 \text { - the spread of } \\
\text { tribal militias } \\
\text { and gangs of } \\
\text { armed robbery } \\
4 \text { The great } \\
\text { presence of the } \\
\text { international } \\
\text { and regional } \\
\text { agenda on the } \\
\text { scene in Darfur } \\
\text { and the proxy } \\
\text { war the } \\
5 \text {. Wars in the } \\
\text { neighboring } \\
\text { countries of } \\
\text { Chad and } \\
\text { Central Africa } \\
6 . \text { Separation of } \\
\text { Southern Sudan } \\
7-\text { The negative } \\
\text { role of } \\
\text { Darfurian elites } \\
\text { of all kinds } \\
8 \text { - Continued } \\
\text { fragmentation } \\
\text { in the armed } \\
\text { movements and } \\
\text { the beginning of } \\
\text { the emergence } \\
\text { of the Arab } \\
\text { dimension in } \\
\text { resolving the } \\
\text { problem of } \\
\text { Darfur } \\
\text { 9. Lack of trust } \\
\text { between the } \\
\text { government and } \\
\text { armed } \\
\text { movements } \\
\text { 10 - continued } \\
\text { fragmentation } \\
\text { and emergence of } \\
\text { ambitions }\end{array}$ \\
\hline
\end{tabular}




\begin{tabular}{|c|c|c|c|c|c|}
\hline Date & $\begin{array}{l}\text { The name of } \\
\text { the agreement }\end{array}$ & Place of signature & Objectives & Results & $\begin{array}{lr}\text { Reasons } & \text { for } \\
\text { success } & \text { or } \\
\text { stumbling } & \end{array}$ \\
\hline & & & & & $\begin{array}{l}\text { personal and } \\
\text { family in the } \\
\text { start } \\
\text { positions and } \\
\text { competition for } \\
\text { positions } \\
11 . \\
\text { International } \\
\text { and regional } \\
\text { agenda } \\
12 \text { - the control } \\
\text { of tribal and } \\
\text { regional trends }\end{array}$ \\
\hline 2009 & $\begin{array}{l}\text { Goodwill } \\
\text { agreement } \\
\text { between the } \\
\text { government } \\
\text { and the } \\
\text { Justice and } \\
\text { Equality } \\
\text { Movement }\end{array}$ & $\begin{array}{l}\text { The capital of the } \\
\text { State of Qatar } \\
\text { (Doha) }\end{array}$ & $\begin{array}{lr}\text { Attaching } & \text { armed } \\
\text { movements } & \text { that } \\
\text { reject the peace } \\
\text { process }\end{array}$ & $\begin{array}{l}\text { The } \\
\text { agreement } \\
\text { was not } \\
\text { implemented } \\
\text { on the ground }\end{array}$ & $\begin{array}{l}\text { The continued } \\
\text { fragmentation } \\
\text { of armed } \\
\text { movements and } \\
\text { the beginning of } \\
\text { the emergence } \\
\text { of arab } \\
\text { intervention in } \\
\text { solving the } \\
\text { problem } \\
\text { Darfur of }\end{array}$ \\
\hline 2010 & $\begin{array}{l}\text { Framework } \\
\text { Agreement } \\
\text { between the } \\
\text { Government } \\
\text { and the } \\
\text { Justice and } \\
\text { Equality } \\
\text { Movement }\end{array}$ & $\begin{array}{l}\text { The capital of the } \\
\text { State of Qatar } \\
\text { (Doha) }\end{array}$ & $\begin{array}{l}\text { To bring non- } \\
\text { signatory } \\
\text { movements to the } \\
\text { Abuja Agreement to } \\
\text { the peace process }\end{array}$ & $\begin{array}{l}\text { The } \\
\text { agreement has } \\
\text { not been } \\
\text { complied with }\end{array}$ & $\begin{array}{l}\text { 1. Lack of trust } \\
\text { between the } \\
\text { government and } \\
\text { armed } \\
\text { movements } \\
2 \text { - Continuation } \\
\text { of } \\
\text { fragmentation. } \\
3 \quad-\quad \text { The } \\
\text { emergence of } \\
\text { greed, personal } \\
\text { and family } \\
\text { competition in } \\
\text { political } \\
\text { positions. } \\
3 \text {. The } \\
\text { international } \\
\text { and regional } \\
\text { agenda } \\
4 \quad-\quad \text { a clear } \\
\text { increase } \\
\text { tribal of } \\
\text { regional and } \\
\text { tendencie }\end{array}$ \\
\hline 2010 & $\begin{array}{l}\text { The } \\
\text { Framework } \\
\text { Agreement } \\
\text { between the } \\
\text { Government } \\
\text { of the Sudan } \\
\text { and the } \\
\text { Liberation }\end{array}$ & $\begin{array}{l}\text { The capital of the } \\
\text { State of Qatar } \\
\text { (Doha) }\end{array}$ & $\begin{array}{l}\text { Attaching armed } \\
\text { movements that } \\
\text { refuse to sign the } \\
\text { peace agreement to } \\
\text { the peace process }\end{array}$ & $\begin{array}{l}\text { The two sides } \\
\text { committed } \\
\text { themselves to } \\
\text { the agreement } \\
\text { and } \\
\text { continue to } \\
\text { dialogue and } \\
\text { negotiations }\end{array}$ & $\begin{array}{l}\text { There is a desire } \\
\text { on both sides to } \\
\text { reach } \\
\text { agreement }\end{array}$ \\
\hline
\end{tabular}




\begin{tabular}{|c|c|c|c|c|c|}
\hline Date & $\begin{array}{l}\text { The name of } \\
\text { the agreement }\end{array}$ & Place of signature & Objectives & Results & $\begin{array}{lr}\text { Reasons } & \text { for } \\
\text { success } & \text { or } \\
\text { stumbling } & \end{array}$ \\
\hline & $\begin{array}{l}\text { Movement } \\
\text { and Justice } \\
\text { (Tijani Sisi) }\end{array}$ & & & & \\
\hline 2010 & $\begin{array}{l}\text { Cease-fire } \\
\text { agreement } \\
\text { between the } \\
\text { Movement for } \\
\text { Liberation } \\
\text { and Justice } \\
\text { and the } \\
\text { Government } \\
\text { of the Sudan }\end{array}$ & $\begin{array}{l}\text { The capital of the } \\
\text { State of Qatar } \\
\text { (Doha) }\end{array}$ & $\begin{array}{l}\text { Preparing for the } \\
\text { signing of the Doha } \\
\text { Document for } \\
\text { Darfur Peace }\end{array}$ & $\begin{array}{l}\text { The two sides } \\
\text { committed } \\
\text { themselves to } \\
\text { an agreement } \\
\text { and to } \\
\text { continue } \\
\text { negotiations }\end{array}$ & $\begin{array}{l}\text { There is a desire } \\
\text { to reach } \\
\text { agreement on } \\
\text { both sides }\end{array}$ \\
\hline 2010 & $\begin{array}{l}\text { Doha Peace } \\
\text { Document in } \\
\text { Darfur }\end{array}$ & $\begin{array}{l}\text { The capital of the } \\
\text { State of Qatar } \\
\text { (Doha) }\end{array}$ & $\begin{array}{l}\text { Achieving peace in } \\
\text { Darfur }\end{array}$ & $\begin{array}{l}\text { 1. The } \\
\text { Convention } \\
\text { was signed } \\
\text { with the } \\
\text { presence and } \\
\text { guarantee of } \\
\text { the } \\
\text { international } \\
\text { community } \\
2 \text {. Convening } \\
\text { of the donor } \\
\text { conference for } \\
\text { the } \\
\text { reconstruction } \\
\text { of Darfur } \\
3 \\
\text { regional The } \\
\text { authority for } \\
\text { Darfur was } \\
\text { formed under } \\
\text { the leadership } \\
\text { of Dr. Tijani } \\
\text { Sisi }\end{array}$ & $\begin{array}{l}\text { To push for } \\
\text { peace by the } \\
\text { international } \\
\text { community, } \\
\text { donors, the } \\
\text { African Union } \\
\text { and the United } \\
\text { Nations, in } \\
\text { addition to the } \\
\text { great pole } \\
\text { played by Doha } \\
\text { in penetrating } \\
\text { the Darfur } \\
\text { crisis in order to } \\
\text { achieve peace. }\end{array}$ \\
\hline
\end{tabular}

The table is designed by the researcher based on different sources. ${ }^{(1),(2),(3),(4),(5)}$

\section{Methodology:}

From the table above, it is clear that, the vast amount of agreements, declarations of principles and other efforts made by mediators from different quarters, all of which have failed to reach an agreement to end the conflict in Darfur in a sustainable manner.

The strategic question is still pending: all these efforts, why did not bear fruit? Despite all these agreements and initiatives, why is the conflict still going on? What are the reasons behind the failure of these agreements and protocols, which made them unable to achieve peace and stop the war?

We hope to contribute to the answer through the questionnaire and analysis below:

\section{Population and study sample:}

The study population means the total set of elements through which the researcher seeks to disseminate the results related to the problem studied. The original study population consists of all residents of Darfur.

\footnotetext{
1 Dr. Al - Tijani Mustafa Mohammed Saleh: Causes of Tribal Conflict in Sudan, Paper presented at the seminar (Visions on Tribal Conflicts in Sudan), Institute of African and Asian Studies, University of Khartoum, 1998.

2 A.Y.Atta, The Mechanism of Armed Tribal Conflicts in South Darfur, Sudanese Writings Magazine, No. 31, March 2005.

3 Z. El Behairy, Darfur: The Origins of the Crisis and the Implications of the International Criminal Court, Cairo, Al-Nahda Egyptian Library, 2008, p. 185.

4 Voluntary Organizations Working in Sudan, Sudanese Council of Voluntary Societies.

5 Documents of tribal reconciliation, Ministry of Local Government, Nyala, South Darfur State.
} 
The study sample was randomly selected from the study population, where the researcher distributed (200) questionnaires to the targeted.

In order to come up with as accurate results as possible, the researcher was keen on the diversity of the sample of the study in terms of including the following:

Individuals of both sexes

2 - Individuals of different age groups

3. Individuals of different academic qualifications

4. Individuals from different tribes (Fur, Brno, Zaghawa, Tamah, Barqou, Daju, Habbaniyah, Maslamiya, Hawara, Masalit, etc.).

5. Individuals from various professional positions (managers, doctors, human rights activist, political activist, teachers, tribal leaders, lawyers, students, farmers, policemen, merchants, others).

6. Foreign aid workers (20 persons)

7. IDPs in Kalma camps in South Darfur, Hasahayisa in West Darfur and Abu Shouk in North Darfur (an average of 30 IDPs from each camp)

8. Individuals of different marital status.

The questionnaire, consisting of one main question and twelve hypothesis, was distributed to the selected sample of the study.

Data and information were emptied in tables prepared by the researcher for this purpose, where the nominal variables (strongly agree, agree, neutral, disagree, strongly disagree) were converted into quantitative variables . $(5,4,3,2,1)$

The main question: "What do you think are the most important reasons that led to the failure of all the agreements that were made to bring peace to Darfur?"

The Hypothesis \# 1: The lack of a clear intellectual and programmatic vision of the political and armed opposition, through which to deal with the international community, has further complicated the crisis in Darfur and thus the inability to reach a sustainable peace agreement.

Table (1): Repetitive distribution of the responses of the study sample to the Hypothesis \# 1

\begin{tabular}{|r|r|r|r|}
\hline \multicolumn{1}{|c|}{ No } & Choices & \# Answers & $\%$ \\
\hline 1 & Strongly Disagree & 34 & 17.2 \\
\hline 2 & Disagree & 30 & 15.2 \\
\hline 3 & neutral & 9 & 4.5 \\
\hline 4 & Agree & 67 & 33.8 \\
\hline 5 & strongly agree & 58 & 29.3 \\
\hline 6 & Total & 198 & 100 \\
\hline
\end{tabular}

Source: Researcher preparation from the field study, SPSS program, 2016

Table (1) shows that (125) individuals in the study sample (63.1\%) agree and strongly agree with Hypothesis \# 1 , and 64 individuals (32.4\%) disagree and strongly disagree.

The Hypothesis \# 2: The multiplicity of international platforms and their contradictions and conflicts of interest and agenda have prolonged the conflict in Darfur.

Table (2): Repetitive distribution of the responses of the study sample to the Hypothesis \# 2

\begin{tabular}{|r|l|r|r|} 
No & Choices & \# Answers & \multicolumn{1}{c|}{$\%$} \\
\hline 1 & Strongly Disagree & 27 & 13.6 \\
\hline 2 & Disagree & 29 & 14.6 \\
\hline 3 & Neutral & 7 & 3.5 \\
\hline 4 & Agree & 60 & 30.3 \\
\hline 5 & strongly agree & 75 & 37.9 \\
\hline 6 & Total & 198 & 100 \\
\hline
\end{tabular}

Source: Researcher preparation from the field study, SPSS program, 2016

Table (2) shows that 135 individuals in the study sample (68.2\%) agree and strongly agree with Hypothesis \# 2 , only 56 individuals $(28.2 \%)$ disagreed and strongly disagreed. 
The Hypothesis \# 3: The decline of the concept of national liberation movements in the world, after the collapse of the Socialist bloc, put the armed movements in Darfur and their political bodies under the influence of various international agenda and interests.

Table (3): Repetitive distribution of the responses of the study sample to the Hypothesis \# 3

\begin{tabular}{|r|r|r|r|}
\hline No & Choices & \# Answers & $\%$ \\
\hline 1 & Strongly Disagree & 26 & 13.1 \\
\hline 2 & Disagree & 51 & 25.8 \\
\hline 3 & Neutral & 17 & 8.6 \\
\hline 4 & Agree & 43 & 21.7 \\
\hline 5 & strongly agree & 61 & 30.8 \\
\hline 6 & Total & 198 & 100 \\
\hline
\end{tabular}

Source: Researcher preparation from the field study, SPSS program, 2016

Table (3) shows that (104) individuals in the study sample, with a percentage (52.5\%) agree and strongly agree with Hypothesis \# 3, and there were (77) individuals with a percentage (38.9\%) disagree and strongly disagree.

The Hypothesis \# 4: Globalization, the clash of civilizations and global virtual culture, exacerbated the complexities and prolonged the crisis in Darfur.

Table (4): Repetitive distribution of the responses of the study sample to the Hypothesis \# 4

\begin{tabular}{|l|r|r|r|}
\hline No & Choices & \# Answers & $\%$ \\
\hline 1 & Strongly Disagree & 21 & 10.6 \\
\hline 2 & Disagree & 14 & 20.7 \\
\hline 3 & neutral & 27 & 13.6 \\
\hline 4 & agree & 67 & 33.8 \\
\hline 5 & strongly agree & 42 & 21.2 \\
\hline 6 & Total & 198 & 100 \\
\hline
\end{tabular}

Source: Researcher preparation from the field study, SPSS program, 2016

Table (4) shows that 109 individuals in the study sample (55\%) agree and strongly agree with Hypothesis \# 4 , and only $62(31.3 \%)$ disagree and strongly disagree.

The Hypothesis \# 5: The fact that Darfur has become one of the biggest corridors of the drug trade in Africa and the Middle East has led drug traffickers to support the prolongation of the conflict in Darfur.

Table (5): Repetitive distribution of the responses of the study sample to the Hypothesis \# 5

\begin{tabular}{|l|r|l|l|}
\hline No & Choices & \# Answers & $\%$ \\
\hline 1 & Strongly Disagree & 28 & 14.1 \\
\hline 2 & Disagree & 48 & 24.2 \\
\hline 3 & Neutral & 13 & 6.6 \\
\hline 4 & Agree & 56 & 28.3 \\
\hline 5 & strongly agree & 53 & 26.8 \\
\hline 6 & Total & 198 & 100 \\
\hline
\end{tabular}

Source: Researcher preparation from the field study, SPSS program, 2016

Table (5) shows that 109 individuals in the study sample (\% .155\%) agree and strongly agree with Hypothesis \# 5 , and there were (76) individuals and percentage (38.3\%) disagree, and strongly disagree

The Hypothesis \# 6: Israeli Interests in the Theory of Tightening and Amputation of the Arab World, this impedes access to peace in Darfur.

Table (6): Repetitive distribution of the responses of the study sample to the Hypothesis \# 6

\begin{tabular}{|l|r|l|l|}
\hline No & Choices & \# Answers & $\%$ \\
\hline 1 & Strongly Disagree & 34 & 17.2 \\
\hline 2 & Disagree & 37 & 18.7 \\
\hline 3 & Neutral & 16 & 8.1 \\
\hline 4 & Agree & 64 & 32.3 \\
\hline 5 & strongly agree & 47 & 23.7 \\
\hline 6 & Total & 198 & 100 \\
\hline
\end{tabular}

Source: Researcher preparation from the field study, SPSS program, 2016

Table (6) show that 111 individuals in the study sample (56\%) approve and strongly agree with Hypothesis \# 6. Seventy-one individuals (35.9\%) disagreed and strongly disagreed. 
The Hypothesis \# 7: The absence of voluntary civil society organizations, Arab, Islamic and national, since the beginning of the crisis, Leaving humanitarian action in the hands of foreign organizations has led to the feeling that the people of Darfur are alone in this crisis and that, foreigners are closer to them than their own people.

Table (7): Repetitive distribution of the responses of the study sample to the Hypothesis \#7

\begin{tabular}{|l|r|l|l|}
\hline \# No & Choices & \# Answers & $\%$ \\
\hline 1 & Strongly Disagree & 16 & 8.1 \\
\hline 2 & Disagree & 18 & 9.1 \\
\hline 3 & Neutral & 7 & 3.5 \\
\hline 4 & Agree & 53 & 26.8 \\
\hline 5 & strongly agree & 104 & 52.5 \\
\hline 6 & Total & 198 & 100 \\
\hline
\end{tabular}

Source: Researcher preparation from the field study, SPSS program, 2016

Table (7) shows that (157) respondents in the study sample (79.3\%) agree and strongly agree with Hypothesis \# 7 , and there were (34) individuals and only (17.2\%) disagree and disagree strongly on that.

Hypothesis \# 8: The political and armed opposition does not have a clear perception of the resolution of the crisis and left it to the mediators in the various platforms, this led to conflicting agenda of mediators and thus failed to reach sustainable solutions for the crisis.

Table (8): Repetitive distribution of the responses of the study sample to the Hypothesis \# 8

\begin{tabular}{|l|r|l|l|}
\hline No & Choices & \# Answers & $\%$ \\
\hline 1 & Strongly Disagree & 17 & 8.6 \\
\hline 2 & Disagree & 22 & 11.1 \\
\hline 3 & Neutral & 7 & 3.5 \\
\hline 4 & Agree & 42 & 21.2 \\
\hline 5 & strongly agree & 110 & 55.6 \\
\hline 6 & Total & 198 & 100 \\
\hline
\end{tabular}

Source: Researcher preparation from the field study, SPSS program, 2016

Table (8) shows that (152) respondents in the study sample (76.8\%) agree and strongly agree with Hypothesis \# 8 , there were (39) individuals and only $(19.7 \%)$ disagree and strongly disagree on it.

Hypothesis \# 9: The international struggle for control of the oil and mineral areas and the strategic location of Darfur have added complications to the crisis.

Table (9): Repetitive distribution of the responses of the study sample to the Hypothesis \# 9

\begin{tabular}{|l|r|l|l|}
\hline No & Choices & \# Answers & $\%$ \\
\hline 1 & Strongly Disagree & 11 & 5.6 \\
\hline 2 & Disagree & 12 & 6.1 \\
\hline 3 & Neutral & 16 & 8.1 \\
\hline 4 & Agree & 53 & 26.8 \\
\hline 5 & strongly agree & 106 & 53.5 \\
\hline 6 & Total & 198 & 100 \\
\hline
\end{tabular}

Source: Researcher preparation from the field study, SPSS program, 2016

Table (9) shows that (159) respondents in the study sample (80.3\%) agree and strongly agree with Hypothesis \# 9 , and there were (13) individuals with a percentage (11.7\%) disagree and strongly disagree on it.

Hypothesis \# 10: The violations and atrocities committed by the Janjaweed government militia in Darfur have shattered social cohesion and raised up the ceiling of peace demands.

Table (10): Repetitive distribution of the responses of the study sample to the Hypothesis \# 10

\begin{tabular}{|l|r|l|l|}
\hline No & Choices & \# Answers & $\%$ \\
\hline 1 & Strongly Disagree & 9 & 4.5 \\
\hline 2 & Disagree & 13 & 6.7 \\
\hline 3 & Neutral & 5 & 2.5 \\
\hline 4 & Agree & 39 & 19.6 \\
\hline 5 & strongly agree & 132 & 66.7 \\
\hline 6 & Total & 198 & 100 \\
\hline
\end{tabular}

Source: Researcher preparation from the field study, SPSS program, 2016

Table (10) shows that (171) respondents in the study sample $(86.3 \%)$ agree and strongly agree with Hypothesis \# 10 , and there were (22) individuals with a percentage $(11.2 \%)$ disagree and strongly disagree on it. 
Hypothesis \# 11: Land ownership and tribal areas are the central issue in Darfur, the rights of IDPs in their land, compensation and evacuation of new settlers from outside Darfur to their countries of origin, all prerequisites for the return of IDPs, dismantling of camps and normalization of life.

Table (11): Repetitive distribution of the responses of the study sample to the Hypothesis \# 11

\begin{tabular}{|l|r|l|l|}
\hline No & Choices & \# Answers & $\%$ \\
\hline 1 & Strongly Disagree & 8 & 4 \\
\hline 2 & Disagree & 11 & 5.5 \\
\hline 3 & Neutral & 7 & 3.5 \\
\hline 4 & Agree & 50 & 25.2 \\
\hline 5 & strongly agree & 122 & 61.6 \\
\hline 6 & Total & 198 & 100 \\
\hline
\end{tabular}

Source: Researcher preparation from the field study, SPSS program, 2016

Table (11) shows that (172) respondents in the study sample (86.8\%) agree and strongly agree with Hypothesis \# 11 , and there were (22) individuals with a percentage (9.5\%) disagree and strongly disagree on it.

Hypothesis \# 12: Disbanding all militias without exception, collecting weapons and handing them over to government armed forces and security arrangements are necessary conditions for peace in Darfur.

Table (12): Repetitive distribution of the responses of the study sample to the Hypothesis \# 12

\begin{tabular}{|l|r|l|l|}
\hline No & Choices & \# Answers & $\%$ \\
\hline 1 & Strongly Disagree & 11 & 5.5 \\
\hline 2 & Disagree & 5 & 2.5 \\
\hline 3 & Neutral & 2 & 1 \\
\hline 4 & Agree & 43 & 21.7 \\
\hline 5 & strongly agree & 137 & 69.2 \\
\hline 6 & Total & 198 & 100 \\
\hline
\end{tabular}

Source: Researcher preparation from the field study, SPSS program, 2016

Table (12) shows that (180) respondents in the study sample 90.9\%) agree and strongly agree with Hypothesis \# 12 , and there were (16) individuals with a percentage (8\%) disagree and strongly disagree on it.

\section{Discussion}

We can summarize many of the traditional causes of conflict, all over the world, among which are the causes of the conflict in Darfur.

- The conflict over participation in governance includes the participation of minorities and groups in power, strategies, rights, etc.

- Religious and cognitive conflict around the world.

- Conflicting identities and ethnicities, including race, religion, language and location.

Other causes include the proliferation of weapons and a culture of violence, which paves the way for conflicts, and conflict may also explode as a result of more than one cause at the same time.

In fact, the issue of the conflict in Darfur is old and has not begun today. We have reviewed its historical development, according to recorded history, and avoided the old stories and oral narratives in the period of the Sultanate of Darfur, and all the conflicts that we have mentioned, occurred after the annexation of the Sultanate of Darfur to Sudan (1916), with its current international geographical borders.

It is noteworthy that, in most of the discussions of the Darfur crisis, the point that researchers avoid most is that when Darfur was annexed to Sudan after the defeat of the Sultan Ali Dinar, Darfur was a sovereign state with its political, economic and social system, foreign relations, laws and a sultan army for over five hundred years. .

In fact, the Sultanate of Darfur has been annexed to Sudan, but not integrated into the Sudanese state. It is noteworthy that, in most of the discussions of the Darfur crisis, the point that researchers avoid most, is that when Darfur was annexed to Sudan after the defeat of Sultan Ali Dinar, Darfur was a sovereign state with its political, economic and social system, external relations, laws and a sultan army, for more than five hundred years. .

In fact, the Sultanate of Darfur has been annexed to Sudan, but not integrated into the Sudanese state.

The Sultanate of Darfur, its systems, institutions and laws were retained, which the British colonization benefited in facilitating control and management.

After the independence of Sudan in 1956, Darfur became part of the state of Sudan, but with a system of government controlled by the so-called traditional civil administration and tribes, which have owned their homes and Hawakeer since the time of the Sultanate of Darfur, and governed by laws derived from their customs, traditions and heritage.

All this has led to the complexity of the details of the current Darfur crisis, which is not similar to the 
problems in other peripheral areas in Sudan.

The Darfur crisis is not an ordinary self-centered crisis; it has gone beyond that, and has resulted in issues of national, regional and international dimensions. It is a crowded crisis with conflicting agendas, proxy warfare and settlement of accounts, which has nominated it to be the most complex crisis of the era.

Therefore, traditional solutions do not work in the Darfur crisis, but rather reproduce and prolong the crisis.

There must be a concerted effort by all sectors of society, including scholars, intellectuals, politicians, traditional civil administration, displaced persons in camps, traditional and modern leaders, youth, women, leaders of armed movements and tribal elders.

What is stated above, requires sincere will and desire of the central government to resolve the crisis, by touching the roots of the problem transparently, and willingness to meet all its dues, so as, to get out of this historic impasse in Darfur, and achieve sustainable peace.

\section{Conclusion}

Based on the historical narrative of the peace agreements that have been held since the outbreak of the Darfur conflict in 2003, which took on a regional political and armed nature, and also by drawing on the results of the analysis of the questionnaire, we conclude that the crisis in Darfur needs radical treatment, at various levels, and the introduction of a phased system. And priorities, in order to obtain sustainable results and how to shape the future of governance in Sudan.

The first essential step is the process of establishing peace, a ceasefire, security arrangements and imposing state prestige.

It is important that the peace documents contain solutions to the problem of land ownership, Hawakir and historical rights in this, because it has become the central issue in Darfur.

It is also important that the peace documents contain the subject of compensation in detail.

After that, the displaced persons who wish to return to their areas from which they were displaced will be provided with housing, health and educational services, clean water and security.

At the end of this step, all militias will be disbanded or integrated into the SAF as appropriate.

The second step or phase has a strategic dimension, which relates to the process of positive discrimination in Darfur and other underdeveloped areas in Sudan, through national development plans, using the system of (Area Specific Plan), according to local needs, in order to be attached to modern civil society in terms of human development, service and infrastructure.

In conclusion, we must always bear in mind that the steadfastness and success of the peace process is based on two things:

The first is that, although there is general agreement among academic researchers on the desired policies and applications in post-conflict societies - including economic growth, overall economic structure building, and transitional justice - there is little understanding of how the timing and sequence of these policies affect Postconflict transition results.

The second, it is noted that many studies in post-conflict reconstruction tend to study a narrow horizon, focusing on policies of political or economic reforms; this underestimates the real complexity of the transition of post-conflict societies and keeps doors closed to other aspects. From rebuilding, such as rebuilding social relationships and trust, as well as psychological therapies that are always present in those communities. $\left({ }^{1}\right)$

\section{References}

$>$ A.Y.Atta, the Mechanism of Armed Tribal Conflicts in South Darfur, Sudanese Writings Magazine, No. 31, March 2005.

$>$ Arnim Langer \&Graham K. Brown, Building Sustainable Peace, Oxford University Press, 2016.

$>$ Documents of Al-Fasher conference for resolving Darfur crisis, July 5, 2010.

$>$ Documents of tribal reconciliation, Ministry of Local Government, Nyala, South Darfur State.

$>$ Dr. Al - Tijani Mustafa Mohammed Saleh: Causes of Tribal Conflict in Sudan, Paper presented at the seminar (Visions on Tribal Conflicts in Sudan), Institute of African and Asian Studies, University of Khartoum, 1998.

$>$ Dr. M. Al-Sharif: Land Ownership and Governance in Darfur, Paper presented to the Peace building Workshop, Center for Western Sudan Studies, Nyala, 2005, p. 6.

$>$ Gerard Brunner, the Mysterious Darfur Massacres, Hatters \& Co. Printing, London, 2005

> http://newsbbc.co.uk/hi/arabic/news/newsid_7922000/7922947/stm

$>\mathrm{http}: / / \mathrm{www}$. allafrica.com/integrated regional information/2004

$>$ http://www.un.org/news/dh/Sudan/com Inq darfur.pdf\#search

$>$ Issue of arrest warrant for Sudanese President, BBC Arabic, Published March 4, 2009, filed August 8, 2017.

\footnotetext{
${ }^{1}$ Arnim Langer \&Graham K. Brown, Building Sustainable Peace, Oxford University Press, 2016.
} 
$>$ Mahmoud Yusuf, Background to the genocide in Darfur, Darfurna.homestead.com

$>$ Noam Choucair: Geography and History of Sudan, Part I, Beirut, 1967, p. 472.

$>$ Sharif Dahab, History of Conflicts in Darfur, Free Pens, JEM Website, April 2018.

$>$ Voluntary Organizations Working in Sudan, Sudanese Council of Voluntary Societies.

$>$ Z. El Behairy, Darfur: The Origins of the Crisis and the Implications of the International Criminal Court, Cairo, Al-Nahda Egyptian Library, 2008, p. 185. 